\title{
Alterations in Blood Parameters According to Activation and Remission Status of Chronic Central Serous Chorioretinopathy
}

\section{Kronik Santral Seröz Koryoretinopatinin Aktivasyon ve Remisyon Dönemlerine ait Kan Paramatrelerindeki Değişimler}

\section{Buğra Karasu đ}

University of Health Sciences, Beyoglu Eye Training and Research Hospital, Istanbul, Turkey

Cite as: Karasu B. Alterations in blood parameters according to activation and remission status of chronic central serous chorioretinopathy. Kocaeli Med J 2021;10(2):83-90.

\begin{abstract}
INTRODUCTION: The aim of this study was to investigate the changes in blood parameters during the activation and remission periods of chronic central serous chorioretinopathy (cCSCR).

METHODS: In this retrospective study, results of the blood parameters of 36 patients (Group 1) with cCSCR during activation period and 41 patients (Group 2) with cCSCR during remission period were recorded.

RESULTS: The mean serum white blood cell $(\mathrm{WBC})$ values in Group 1 were $7.87 \pm 2.21\left(10^{\wedge} 3 / \mathrm{LL}\right)$ and in Group 2, $7.35 \pm 1.26\left(10^{\wedge} 3 / \mathrm{LL}\right)$ were not statistically significant $(\mathrm{p}=0.390)$. The mean serum levels of red blood cells $(\mathrm{RBC})$ were $5.07 \pm 0.42\left(10^{\wedge} 6 / \mathrm{LL}\right)$ in Group 1 and $4.98 \pm 0.63\left(10^{\wedge} 6 / \mathrm{LL}\right)$ in Group $2(\mathrm{p}=$ $0.321)$, respectively. The mean serum levels of platelet (PLT) were $237.58 \pm 53.08\left(10^{\wedge} 3 / \mathrm{LL}\right)$ in Group 1 and $218.72 \pm 54.16\left(10^{\wedge} 3 / \mathrm{LL}\right)$ in Group $2(\mathrm{p}=0.149)$, respectively. Platelet crite (PCT) levels were significantly increased in Group 1 compared to Group $2(\mathrm{p}=0.003)$. Mean platelet volume (MPV) values were significantly increased in group $1(9.44 \pm 1.17 \mathrm{fL})$ compared to group $2(7.28 \pm 0.76 \mathrm{fL})(\mathrm{p}=0.016)$.

DISCUSSION AND CONCLUSION: High MPV and PCT serum levels during the activation period can provoke the tendency of thrombosis in CCSCR and moreover may induce choroidal ischemia and microinfarct formation.
\end{abstract}

Keywords: chronic central serous chorioretinopathy, blood parameters, activation and remission periods of chronic CSCR

$\ddot{\mathrm{O} z}$

GÍRIŞ ve AMAÇ: Bu çalışmanın amacı kronik santral seröz koryoretinopatide(SSKR) aktivayon ve remisyon dönemlerinde kan parametrelerindeki değişimi incelemek.

YÖNTEM ve GEREÇLER: Bu retrospektif çalışmada, aktivasyon döneminde olan kronik SSKR'li 36 hasta (Grup 1) ve remisyon dönemindeki kronik SSKR'li 41 hasta (Grup 2)' nın kan parametreleri kayıt altına alındı. Çalışmaya dahil edilen tüm hastalardan venöz kan örnekleri alındı ve tam kan sayımı yapıldı. Her bir grupta kan parametrelerinin sonuçları analiz edildi.

BULGULAR: Ortalama serum beyaz kan hücresi (WBC) değerleri Grup 1'de $7.87 \pm 2.21(10 \wedge 3 /$ $\mathrm{uL})$ ve Grup 2 'de $7.35 \pm 1.26\left(10^{\wedge} 3 / \mathrm{uL}\right)$ istatiksel olarak anlamlı değildi $(\mathrm{p}=0.390)$. Kırmızı kan hücrelerinin(RBC) ortalama serum düzeyi Grup 1'de $5.07 \pm 0.42\left(10^{\wedge} 6 / \mathrm{uL}\right)$ ve Grup 2 'de $4.98 \pm 0.63$ $\left(10^{\wedge} 6 / \mathrm{uL}\right)$ idi $(\mathrm{p}=0.321)$. Trombosit(PLT) ortalama serum düzeyi Grup 1'de 237.58 $\pm 53.08(10 \wedge 3 /$ $\mathrm{uL})$ ve Grup 2'de 218.72 $\pm 54.16\left(10^{\wedge} 3 / \mathrm{uL}\right)$ idi $(\mathrm{p}=0.149)$. Trombosit krit $(\mathrm{PCT})$ düzeyleri Grup 1 'de Grup 2'ye göre anlamlı olarak artmıştı $(\mathrm{p}=0.003)$. Ortalama platelet hacmi (MPV) değerleri grup 1'de $(9.44 \pm 1.17 \mathrm{fL})$ grup 2'ye göre $(7.28 \pm 0.76 \mathrm{fL})$ istatiksel olarak anlamlı oranda artmıştı $(\mathrm{p}=0.016)$.

TARTIŞMA ve SONUÇ: Aktivasyon süresi boyunca MPV ve PCT'nin yüksek serum seviyeleri, kronik SSKR'de tromboza eğilimi arttırabilmekte ve koroidal iskemi ile birlikte mikroinfakt oluşumunu tetikleyebilmektedir.

Anahtar Kelimeler: Kronik santral seröz koryoretinopati, kan parametreleri, kronik SSKR'nin aktivasyon ve remisyon dönemleri.
Geliş tarihi / Received:

29.02.2020

Kabul tarihi / Accepted:

05.08.2021

\author{
Sorumlu Yazar/Corresponding Author: \\ Buğra Karasu \\ University of Health Sciences, Beyoglu \\ Eye Training and Research Hospital, \\ Istanbul, Turkey \\ bugra_karasu@hotmail.com \\ ORCID: 0000-0001-7362-4453
}




\section{INTRODUCTION}

Central serous chorioretinopathy (CSCR) is a chorioretinal disease that causes vision loss by inducing fluid accumulation among neurosensory retina and retinal pigment epithelium (RPE) (1). It generally progresses to unilateral eye involvement in young-middle-aged men and is known for its recurrent clinical course $(2,3)$. Genetic factors, uncontrollable hypertension (HT), sympathetic-parasympathetic instability, pregnancy, high blood cortisone levels, type A personality, stress, gastroesophageal reflux and apne disorders are among the risk factors for the predisposition of CSCR (4-8). Although the pathogenesis of CSCR is controversial, a growing number of studies have shown that a focal, temporary or permanent capillary occlusion is responsible for RPE decompensation followed by neurosensory retinal detachment (7). Chronic CSCR (cCSCR) is diagnosed when mentioned above symptoms last-longer than 6 months (1).

In a recent study, it has been reported that increased platelet aggregation and impaired fibrinolysis in the choriocapillaris level play a role in the pathogenesis of CSCR (9). Mean platelet volume (MPV), which can be easily assessed with a routine complete blood count (CBC) is an indicator of platelet (PLT) size and is known to be a potentially useful biomarker of PLT activity. Large PLTs are metabolically and enzymatically more reactive and have a stronger pro-thrombotic efficacy (10). MPV is known to be associated with many systemic diseases. In recent years it has been shown to be associated with ocular disorders such as retinal vein occlusion, retinopathy of prematurity, pseudoexfoliation syndrome and diabetic retinopathy (11-14).

To the best of our knowledge, there are limited number of studies in the literature evaluating blood parameters, especially platelet functions in patients with CSCR in activation and remission periods. The aim of this study is to investigate a possible blood marker in the early prediction of the disease by evaluating the change in blood parameters in CSCR patients during activation and remission periods.

\section{MATERIAL AND METHODS}

In this retrospective cross-sectional study, medical records and blood parameters of 36 patients (Group 1) with cCSCR in the activation period and 41 patients with $\mathrm{cCSCR}$ in remission period (Group 2) between September 2016 and January 2018 were reviewed. The study which adheres to the principles of the Helsinki Declaration and was approved by the local ethics committee (Ethics committee approval no 2020/17 from Health Sciences Bakırköy Dr. Sadi Konuk Training and Research Hospital Clinical Research Ethics Committee Presidency, 20/01/2020). Informed consent form was obtained from each patient.

The patients were divided into two groups according to ocular examination findings, spectral domain optical coherence tomography (SD-OCT) (HRA-2, Heidelberg Engineering, Heidelberg, Germany) images, fundus fluorescein angiography
(FFA) (HRA-2, Heidelberg Engineering, Heidelberg, Germany) and indocyanine green angiography (ICGA) analysis. Figure 1a shows FFA, ICGA and SD-OCT images of a patient with cCSCR in remission period. Figure $1 \mathrm{~b}$ shows the FFA, ICGA and SD-OCT images of a patient with active cCSCR.

Central macular thickness (CMT) and subfoveal choroidal thickness(SFCT)oftheparticipantswerecalculatedbyautomatic measurement in SD-OCT. Optical coherence tomography angiography (OCTA) was used to measure vascular density (VD) of the deep capillary plexus (DCP) and choriocapillaris which evaluates ischemia or perfusion deterioration in the activation and remission period. Before these procedures to be performed in our clinic, laboratory analyzes were routinely implemented

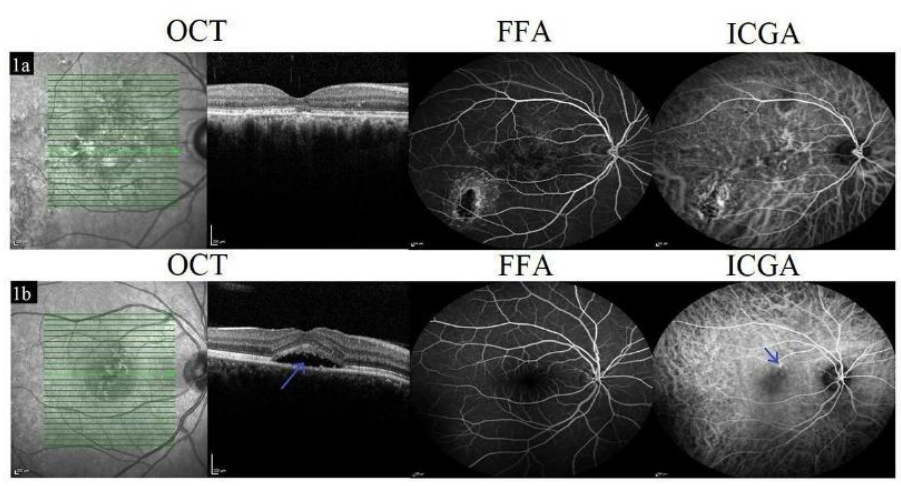

Figure 1a. Fundus fluorescein angiography (FFA), indocyanine green angiography (ICGA) and spectral domain optical cohrence tomography (SD-OCT) images of a patient with cCSCR in remission period.

Figure $1 \mathrm{~b}$. FFA, ICGAand SD-OCTimages of a patient with active CCSCR.

\section{OCT image of active CSCR}
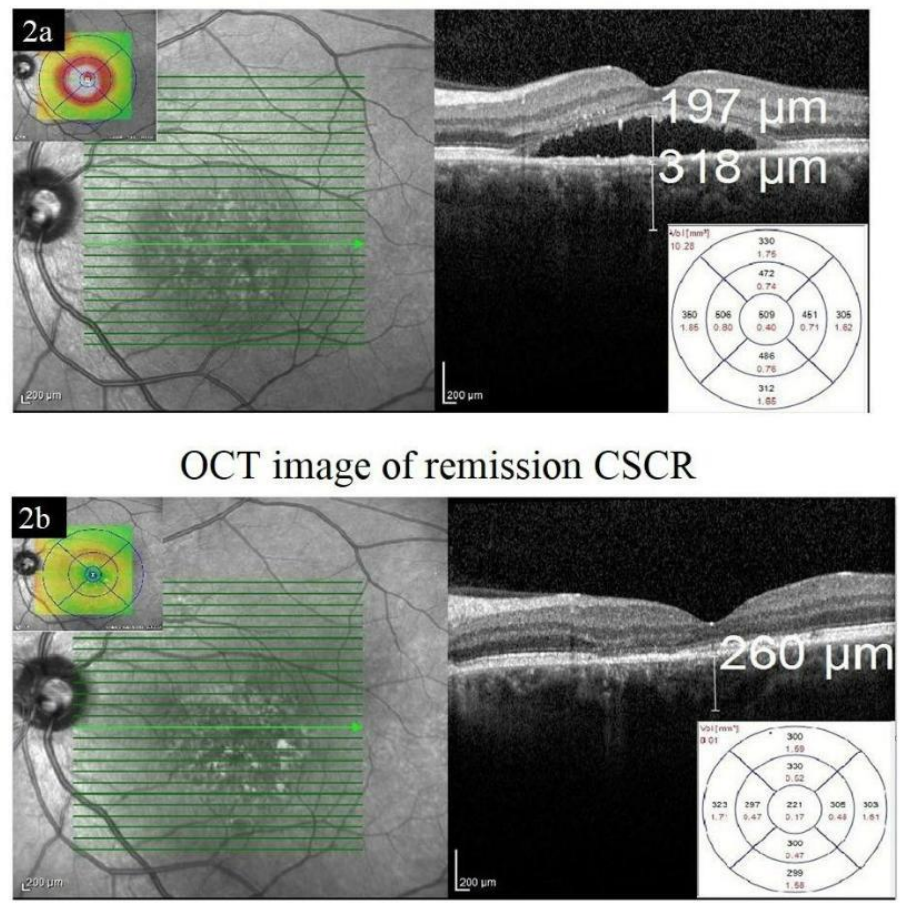

Figure 2a. CMT and SFCT measurements of another patient in the activation period have been shown.

Figure 2b. CMT and SFCT measurements of the same patient in remission have been shown. 


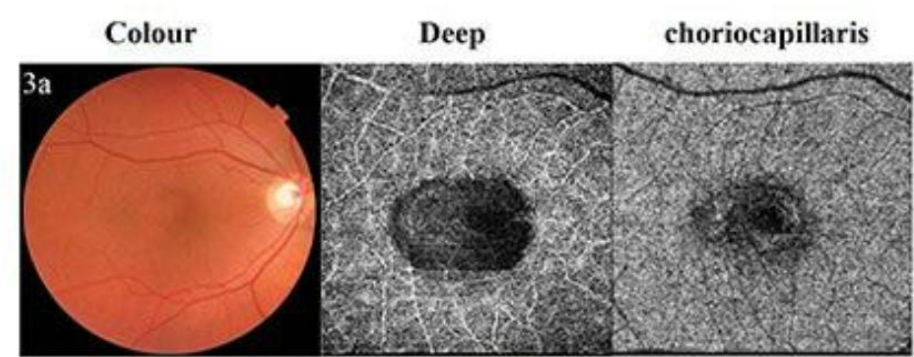

Vessel Density and OCT

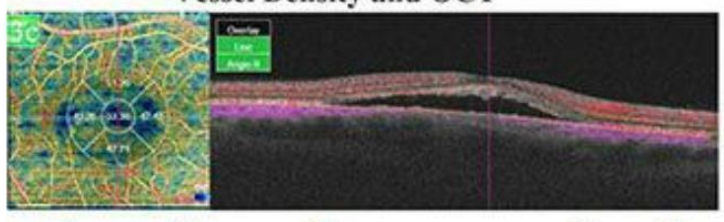

Activation period

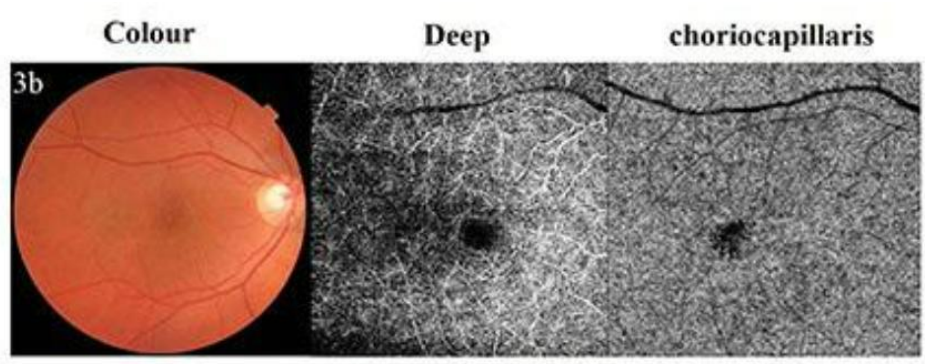

Vessel Density and OCT

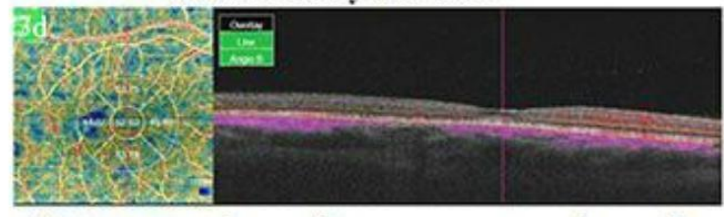

Remission period

Figure 3. Optical cohrence tomography angiography (OCTA) images have been displayed the deep capillary plexus and choriocapillaris vessel density of a patient with activation $(3 \mathrm{a}, 3 \mathrm{c})$ and remission $(3 \mathrm{~b}, 3 \mathrm{~d})$ periods.

" Group 1 (active)

" Group 2 (remission)
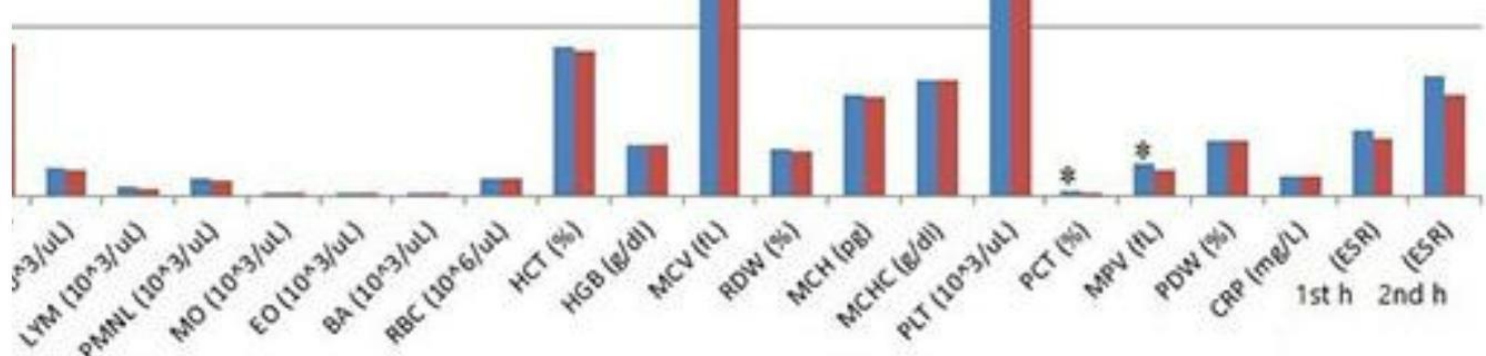

Figure 4. Blood parameters of patients with cCSCR during activation and remission periods are summarized in the graphs. WBC, white blood cell; LYM, lymphocyte; PMNL, neutrophil; MO, monocyte; EO, eosinophil; BA, basophil; RBC, red blood cell; HCT, hematocrit; Hgb, hemoglobin; CRP, C-reactive protein; MCV, mean corpuscular volume; RDW, red blood cell distribution width; MCH, mean corpuscular hemoglobin; MCHC, mean corpuscular hemoglobin concentration; PLT, platelet; PCT, platelet crit; MPV, mean platelet volume; PDW, platelet distribution width.

\section{Activation period of cCSCR}

It is characterized by multifocal, irregularly distributed and varying degrees of diffuse RPE depigmentation combined with serous neurosensory and/or RPE detachment.

\section{Remission period of cCSCR}

Patients who were diagnosed with CCSCR in our clinic and did not meet any activation criteria within the last 1 year were included in this group (15). 


\section{Optical coherence tomography angiography measurements}

Optical coherence tomography angiography imaging of eyes was implemented with the Topcon Dri Triniton device (version 1.17.9720; Topcon Medical Systems, Inc, Oakland, NJ). High quality 9x9 mm images were selected on the fovea with strong signal-to-noise ratio and sufficient centralization. An automatic segmentation system was used to evaluate projections of DCP and choriocapillaris by Angiogram module. If errors were detected in the segmentation phase, manual correction was done via the software program. The DCP was adjusted inside of inner border within $10 \mu \mathrm{m}$ of the inner plexiform layer (IPL) and outer border at $10 \mu \mathrm{m}$ beneath the outer plexiform layer (OPL). Images of the choriocapillaris extending $10.4 \mu \mathrm{m}$ under the Bruch membrane were based on automatic segmentation method. The ratio of the area occupied by the vascular system with OCTA was calculated and defined as the analysis of VD. Figure 3 shows OCTA images showing the DCP and choriocapillaris VD of a patient with activation and remission periods.

\section{Exclusion criteria;}

Diabetes mellitus (DM), HT, current smoking status and history, renal failure, hyperthyroidism, hypothyroidism, chronic obstructive pulmonary disease, liver diseases, blood disorders causing anemia, malignancy, any cardiovascular disorders, acute infectious disease, using anti-inflammatory drugs, anticoagulant drugs, and oral contraceptives were excluded from the study. In addition, patients who received systemic medical therapy were excluded from the study (systemic carbonic anhydrase inhibitors (CAIs) or anti-inflammatory therapy). Patients with a history of ocular disease and usage of any drug including immunosuppressive therapy were excluded from the study. Besides, patients with chronic eye disease (such as glaucoma, uveitis) and any retino-choroidal disease that could be confused with a cCSCR diagnosis were also excluded.

There were no findings in the blood parameters showing liver and kidney function tests in both groups and in the histories of the patients. In order to standardize the hemostatic parameter measurements, all procedures for the participants in the study were performed on a fasting in the morning. $\mathrm{CBC}$ values such as red blood cell (RBC), MPV, PLT count, PLT crite (PCT), white blood cell (WBC), lymphocyte (LYM), neutrophil (PMNL), hemoglobin ( $\mathrm{Hgb})$ and hematocrit (HCT) were recorded. A complete ophthalmologic examination including best corrected visual acuity (BCVA) with Snellen chart, biomicroscopic examination, intraocular pressure (IOP) measurement with Goldmann applanation tonometer and dilated pupil examination of the fundus were performed in all study groups.

\section{Inter-rater and Intra-rater agreement}

$20 \%$ of the total images (16 images) were initially divided by the evaluators in order to accurately provide inter-rater agreement. The same set of images was segmented into sections by a different classifier after a 5-day interval to calculate the rater's reliability. Inter-rater and intra-rater reliability for image duplication was assessed using the exact agreement model of the intraclass correlation coefficient (ICC). SFCT measurements were obtained according to Bland Altman analysis (16).

\section{Statistical analysis}

Descriptive statistical methods (mean, standard deviation, minimum and maximum values) were used in the present study. KolmogorovS mirnovtestwasusedtoanalysetheappropriateness of data distribution. Statistical analysis was done by independent t-test for multiple comparisons. Differences in age and gender between the two groups were analyzed using student $t$ test or Mann-Whitney U test for homogeneous or non-homogeneous distributions. Pearson correlation coefficient test was used to find the correlation between groups. Results were analyzed using IBM SPSS 20 software system (SPSS Inc., Chicago, IL, USA). Statistical significance was set out at $\mathrm{p}<0.05$.

\section{RESULTS}

The data of 77 patients with cCSCR were retrospectively analyzed and recorded. There were 29 (37\%) female and 48 (63\%) male patients in the study. The mean age was $46.38 \pm$ 9.34 years (range, 36-65 years) in Group 1 and $45.02 \pm 7.36$ years (range, 25-63 years) in Group 2, respectively. There was no difference between two groups in terms of age $(p=0.47)$ or gender $(\mathrm{p}=0.79)$ (Table 1). Intra-examiner ICC value for SFCT was 0.995 (95\% confidence interval, 0.990-0.997) and inter-examiner ICC was 0.997 (95\% confidence interval, 0.995 0.999).

Central macular thickness values were significantly higher in Group 1 than Group $2(489.42 \pm 76.94 \mu \mathrm{m}$ in Group 1 and 237.67 $\pm 81.93 \mu \mathrm{m}$ in Group 2) ( $\mathrm{p}<0.001)$. The same situation was similar for SFCT measurements $(343.74 \pm 91.67 \mu \mathrm{m}$ in Group 1 and $249.71 \pm 87.90 \mu \mathrm{m}$ in Group 2$)(\mathrm{p}<0.001)$. A statistically significant higher was observed in Group 2 in terms of deep capillary plexus (DCP) and choriocapillaris vessel density (VD) $(p<0.05)$. Table 2 shows the results for SFCT, CMT and VD of DCP and choriocapillaris.

White blood cell values were not statistically significantly different in Group $1\left(7.87 \pm 2.21-10^{\wedge} 3 / \mathrm{uL}\right)$ compared to Group $2\left(7.35 \pm 1.26-10^{\wedge} 3 / \mathrm{LL}\right)(\mathrm{p}=0.390)$. RBC values were not statistically differ in Group $1\left(5.07 \pm 0.42-10^{\wedge} 3 /\right.$ $\mu \mathrm{L})$ compared to Group $2\left(4.98 \pm 0.63-10^{\wedge} 3 / \mathrm{LL}\right)(\mathrm{p}=0.321)$. PLT counts were not statistically significantly different in Group $1\left(237.58 \pm 53.08-10^{\wedge} 3 / \mathrm{uL}\right)$ compared to Group 2 (218.72 \pm $\left.54.16-10^{\wedge} 3 / \mathrm{uL}\right)(\mathrm{p}=0.149)$. PCT values were significantly increased in Group $1(0.22 \pm 0.05 \%)$ compared to Group $2(0.20$ $\pm 0.02 \%)(\mathrm{p}=0.003)$. MPV values were significantly increased in Group $1(9.44 \pm 1.17 \mathrm{fL})$ compared to Group $2(7.28 \pm 0.76 \mathrm{fL})$ 
Tablo 1. Blood parameters of patients with chronic central serous chorioretinopathy (cCSCR) during activation and remission periods.

\begin{tabular}{llll}
\hline Mean \pm SD & Group 1 (active) & Group 2 (remission) & p values \\
\hline & n: 36 & n: 41 & 0.470 \\
Age (years) & $46.38 \pm 9.34$ & $45.02 \pm 7.36$ & 0.790 \\
Cinsiyet (male/female) & $(22 / 14)$ & $(26 / 15)$ & 0.390 \\
WBC (10^3/uL) & $7.87 \pm 2.21$ & $7.35 \pm 1.26$ & 0.597 \\
LYM (10^3/uL) & $2.33 \pm 0.68$ & $2.11 \pm 0.67$ & 0.113 \\
PMNL (10^3/uL) & $4.88 \pm 1.81$ & $4.55 \pm 1.36$ & 0.360 \\
MO (10^3/uL) & $0.47 \pm 0.12$ & $0.50 \pm 0.11$ & 0.936 \\
EO (10^3/uL) & $0.16 \pm 0.10$ & $0.17 \pm 0.10$ & 0.918 \\
BA(10^3/uL) & $0.03 \pm 0.01$ & $0.03 \pm 0.01$ & 0.321 \\
RBC (10^6/uL) & $5.07 \pm 0.42$ & $4.98 \pm 0.63$ & 0.110 \\
HCT (\%) & $44.25 \pm 3.81$ & $43.41 \pm 3.30$ & 0.480 \\
Hgb (g/dl) & $15.31 \pm 1.59$ & $15.27 \pm 1.28$ & 0.155 \\
MCV (fL) & $87.4 \pm 5.20$ & $86.43 \pm 7.19$ & 0.417 \\
RDW (\%) & $13.63 \pm 0.83$ & $13.43 \pm 0.94$ & 0.538 \\
MCH (pg) & $30.17 \pm 2.00$ & $29.68 \pm 2.51$ & 0.286 \\
MCHC (g/dl) & $34.41 \pm 0.80$ & $34.54 \pm 1.07$ & 0.149 \\
PLT (10^3/uL) & $237.58 \pm 53.08$ & $218.72 \pm 54.16$ & $0.003^{*}$ \\
PCT (\%) & $0.22 \pm 0.05$ & $0.20 \pm 0.02$ & $0.016^{*}$ \\
MPV (fL) & $9.44 \pm 1.17$ & $7.28 \pm 0.76$ & 0.225 \\
PDW (\%) & $16.09 \pm 0.31$ & $16.19 \pm 0.41$ & 0.936 \\
CRP (mg/L) & $5.51 \pm 1.55$ & $5.42 \pm 1.18$ & 0.369 \\
Sedimentation 1.hour (ESR) & $19.54 \pm 19.31$ & $17 \pm 16.52$ & 0.331 \\
Sedimentation 2.hour (ESR) & $35.46 \pm 29.52$ & $29.94 \pm 25.23$ &
\end{tabular}

Mann Whitney $U$ test was used for the difference between age and sex.

Independent $t$ test*

WBC, White blood cell; LYM, lymphocyte; PMNL, neutrophil;

MO, monocyte; EO, eosinophil; BA, basophil; RBC, red blood cell; HCT, hematocrit; Hgb,hemoglobin; CRP, C-reactive protein

$\mathrm{MCV}$,mean corpuscular volume; RDW, Red blood cell distribution width;

$\mathrm{MCH}$, mean corpuscular hemoglobin; MCHC, mean corpuscular hemoglobin concentration

PLT, platelet; PCT, platelet crit; MPV, mean platelet volume; PDW, platelet distribution width.

Table 2. The results for subfoveal choroidal thickness (SFCT), central macular thickness (CMT) and vessel density of deep capillary plexus and choriocapillaris have shown.

\begin{tabular}{lccc}
\hline Mean \pm SD & Group 1 (active) & Group 2 (remission) & p values \\
\hline CMT $(\mu \mathrm{m})$ & $489.42 \pm 76.94$ & $237.67 \pm 81.93$ & $<0.001^{*}$ \\
SFCT $(\mu \mathrm{m})$ & $343.74 \pm 91.67$ & $249.71 \pm 87.90$ & $<0.001^{*}$ \\
Deep VD (\%) & $30.49 \pm 10.36$ & $42.49 \pm 11.34$ & $0.001^{*}$ \\
Choriocapillaris VD (\%) & $38.89 \pm 11.91$ & $45.94 \pm 16.31$ & $0.032^{*}$ \\
\hline
\end{tabular}

Independent $\mathrm{t}$ test*

CMT, central macular thickness; SFCT, subfoveal choroidal thickness

VD, vessel density; SD, standard deviaton 
$(p=0.016)$. In Figure 4, the results of blood parameters are summarized in the graphs.

C-reactive protein (CRP) had a positive correlation with RBC ( $r=0.647, p<0.001)$, HCT $(r=0.879, p=0.001)$, Hgb $(\mathrm{r}=0.451, \mathrm{p}<0.001)$ and mean erythrocyte hemoglobin concentration (MCHC) $(r=0.126, p=0.003)$.

\section{DISCUSSION}

This study suggests that MPV and PCT are significantly higher in patients with cCSCR in the activation period and that high MPV and PCT values may be a predictive factor of CCSCR.

Central serous chorioretinopathy is common retino-choroidal disease that often affects young patients and is related to reduced, distorted visual acuity including metamorphopsia (17). Also, it is a complex disease that needs to be understood due to variable clinical course, multifactorial complex pathogenesis, and relationship with systemic drugs and diseases.

A study by Spaide et al. showed that the prevalence of CSCR is higher in men than women (18). The cCSCR has a selective attitude regarding ethnic preferences as well as gender. A higher incidence has been reported in Asian populations and also bilateral and multifocal involvement of the disease course is more common than in other ethnic populations (19).

Platelets play key roles in thrombogenesis and atherogenesis (20). MPV is a widely used indicator blood parameter representing platelet size and activity. Large PLTs exhibit strong pro-thrombotic activity due to being metabolically and enzymatically more reactive (10). And also, high MPV is connected with increment of PLT aggregation, expression of thromboxane, thromboglobulin and serotonin release, and provokes synthesis of adhesion molecules (21). Higher MPV values are a factor blamed in thrombosis-related events and are frequently seen in conditions such as DM, HT, acute myocardial infarction $(20,22)$. It has been reported that high MPV values are also associated with microvascular diseases such as retinopathy and microalbuminuria found in patients with DM as well as macrovascular diseases (23). In a study conducted by Şahin et al, it was shown that patients with retinal artery occlusion have higher MPV values (24).

Platelet crit is a marker of platelets formed per unit blood volume and indicates quantitative abnormalities of PLTs calculated as mean platelet volume (MPV / 107) (25). In the study of Akpinar et al., it was shown that PCT has a predictive feature for venous grafts and can be used as a marker that prevents graft atherosclerosis in patients with bypass surgery (26). A recent study has shown that PCT correlates with CRP in systemic inflammatory response (27). No correlation was found between PCT and CRP $(r=0.613, p=0.187)$ in our study.

Choroid and RPE play a major role in the pathogenesis of cCSCR. Increment of visualized staining in the inner choroid on middle stage of ICGA may provide supportive information about choroidal hyperpermeability in patients with cCSCR (28). Higher hydrostatic pressure of tissues which caused by choroidal hyperpermeability triggers damage to the RPE by an increment in subretinal fluid accumulation (29). In our study, increment of VD in choriocapillaris and DCP by OCTA and reduction of CMT, SFCT and subretinal fluid in SD-OCT during the remission period support this situation. However, the reason for the increased choroidal hyperpermeability has not fully understood yet.

The choroid is considered to be increment of permeability in cCSCR as a possible reason of ischemia or inflammation (30). Staining of the inner choroid which displayed on midphase ICGA is the most important feature of choroidal hyperpermeability $(31,32)$.

Spectral domain optical coherence tomography uses a higher wavelength that provides deeper penetration and higher image quality. One of the most important factors affecting the maximal choroidal thickness area is the large and engorged choroidal vessels (30). Demirel et al. found that SFCT and choroidal area were thicker in eyes with cCSCR, however the stroma / lumen ratio is less affected (33).

Optical coherence tomography angiography is a recently preferred imaging method that provides high-quality images of the retina and outer choroidal vasculature section without any invasive procedure (34). OCTA facilitate to monitorize any vascular changes in the choriocapillaris which structure most likely to be affected by activation of cCSCR and presented that the choriocapillaris layer was severely affected in cCSCR (33).

In a study by lijima et al., they found that plasminogen activator inhibitor-1 level was higher in patients with cCSCR compared to control eyes (35). In a recent study performed by Caccavale et al., administration of low-dose aspirin therapy for patients with cCSCR and has reported that resulted with faster visual recovery and lower recurrence rates compared to an untreated group. They suggested that usage of low-dose aspirin was associated with the decrement of PLT aggregation and increased fibrinolysis occurring in choriocapillaris (9).

Incurrentstudy, weassumedthatchoroidalhyperpermeability in patients with cCSCR may be the result of micro-thrombus formation in choroidal vessels associated with increased PLT aggregation. The results of current study showed that MPV and PCT values, which are a strong indicator of PLT activity, may be significantly higher in patients with CCSCR in the activation period compared to the CCSCR in remission period.

Retrospective design and relatively small sample size can be considered as two major reasons for the limitations of our study. And also the absence of a control group consisting of healthy individuals is one of the limitations of this study.

Another factor that affects MPV level is smoking. Referring to Varol et al study, they have found an increment of MPV in regular smokers and showed a significant decrease in MPV in the third month after give-up smoking (36). In a study of Türkçü et al., it has been reported that poorer visual acuity and the need for longer treatment in CCSCR patients who underwent smoking (37). Therefore, we did not include patients who had smoke. 
In a study performed by Dursun et al., they found that MPVs have relatively higher in cCSCR patients (38). We observed similar results in our study, but we examined patients according to remission and activation periods. Although we screened for conditions such as HT that may affect the MPV, the lack of data on biochemical parameters, including patients' lipid analysis is another limitation for current study.

In conclusion, we believe that slowing of the blood flow which caused increment of viscosity, thrombosis tendency and development of microinfarcts in the choroidal region play an essential role in the pathogenesis of cCSCR. Therefore, we thought that serum levels of PCT and MPV play a key role in the follow-ups of activation or remission period of patients with cCSCR. Further prospective studies are needed to better illuminate the prognosis and find predictive markers of cCSCR status.

\section{Disclosure and Acknowledgments}

Ethical approval: All procedures performed in studies involving human participants were in accordance with the ethical standards of the institutional and/or national research committee and with the 1964 Helsinki declaration and its later amendments or comparable ethical standards.

Informed consent: Informed consent was obtained prior to every surgical procedure from all individual participants included in the study.

Funding: This research received no specific grant from any funding agency in the public, commercial, or notfor-profit sectors.

Conflict of Interest: No conflicting relationship exists for any author.

\section{REFERENCES}

1. Salehi M, Wenick AS, Law HA, Evans JR, Gehlbach P. Interventions for central serous chorioretinopathy: a network meta-analysis. Cochrane Database Syst Rev 2015 Dec 22;(12):CD011841.

https://doi.org/10.1002/14651858.CD011841

2. Saito M, Saito W, Hirooka K, Hashimoto Y, Mori S , Noda $\mathrm{K}$, et al. Pulse waveform changes in macular choroidal hemodynamics with regression of acute central serous chorioretinopathy. Invest Ophthalmol Vis Sci 2015 Oct;56(11):6515-22.

https://doi.org/10.1167/iovs.15-17246

3. Tittl M, Maar N, Polska E, Weigert G, Stur M, Schmetterer L. Choroidal hemodynamic changes during isometric exercise in patients with inactive central serous chorioretinopathy. Invest Ophthalmol Vis Sci 2005 Dec;46(12):4717-21. https://doi.org/10.1167/iovs.05-0268

4. Haimovici R, Koh S, Gagnon DR, Lehrfeld T, Wellik S, Central Serous Chorioretinopathy Case-Control Study Group. Risk factors for central serous chorioretinopathy: a case-control study. Ophthalmology 2004 Feb;111(2):244-9. https://doi.org/10.1016/j.ophtha.2003.09.024

5. Kloos P, Laube I, Thoelen A. Obstructive sleep apnea in patients with central serous chorioretinopathy. Graefes Arch Clin Exp Ophthalmol 2008 Sep;246(9):1225-8. https://doi.org/10.1007/s00417-008-0837-0

6. Mansuetta CC, Mason JO 3rd, Swanner J, Feist RM, White Jr MF, Thomley ML, et al. An association between central serous chorioretinopathy and gastroesophageal reflux disease. Am J Ophthalmol 2004 Jun;137(6):1096-100. https://doi.org/10.1016/j.ajo.2004.01.054

7. Tewari HK, Gadia R, Kumar D, Venkatesh P, Garg SP. Sympathetic-parasympathetic activity and reactivity in central serous chorioretinopathy. Invest Ophthalmol Vis Sci 2006 Aug;47(8):3474-8.

https://doi.org/10.1167/iovs.05-1246

8. Zakir SM, Shukla M, Simi ZU, Ahmad J, Sajid M. Serum cortisol and testosterone levels in idiopathic central serous chorioretinopathy. Indian J Ophthalmol 2009 NovDec;57(6):419-22. https://doi.org/10.4103/0301-4738.57143

9. CaccavaleA, Romanazzi F, Imparato M, NegriA, MoranoA, Ferentini F. Low-dose aspirin as treatment for central serous chorioretinopathy. Clin Ophthalmol 2010 Aug 9;4:899-903. https://doi.org/10.2147/OPTH.S12583

10. Chu SG, Becker RC, Berger PB, Bhatt DL, Eikelboom JW, Konkle B, et al. Mean platelet volume as a predictor of cardiovascular risk: a systematic review and meta-analysis. J Thromb Haemost 2010 Jan;8(1):148-56.

https://doi.org/10.1111/j.1538-7836.2009.03584.x

11. Ateş O, Kiki İ, Bilen H, Keleş M, Koçer İ, Kulaçoğlu DN, et al. Association of mean platelet volume with the degree of retinopathy in patients with diabetes mellitus. Eur J Gen Med 2009; 6:99-102. https://doi.org/10.29333/ejgm/82648

12. Sahin A, Sahin M, Yüksel H, Türkcü FM, Cınar Y, Cingü AK, et al. The mean platelet volume in patients with retinal vein occlusion. J Ophthalmol 2013; 2013: 236371. https://doi.org/10.1155/2013/236371

13. Tao Y, Dong Y, Lu CW, Yang W, Li Q . Relationship between mean platelet volume and retinopathy of prematurity. Graefes Arch Clin Exp Ophthalmol 2015 Oct;253(10):1791-4. https://doi.org/10.1007/s00417-015-2972-8

14. Yazgan S, Celik U, Kaldırım H, Ayar O, Akdemir MO. Platelet crit in ocular pseudoexfoliation syndrome. Eye Contact Lens 2016 Sep;42(5):328-32. https://doi.org/10.1097/ICL.0000000000000197

15. Wang M , Munch IC, Hasler PW, Prünte C, Larsen M. Central serous chorioretinopathy. Acta Opthalmol. 2008; 86:126-145. https://doi.org/10.1111/j.1600-0420.2007.00889.x

16. Bland JM, Altman DG. Agreed statistics: measurement method comparison. Anesthesiology 2012; 116, 182-185. 
https://doi.org/10.1097/ALN.0b013e31823d7784

17. Liegl R, Ulbig MW. Central serous chorioretinopathy. Ophthalmologica 2014;232(2):65-76.

https://doi.org/10.1159/000360014

18. Spaide RF, Campeas L, Haas A, Yannuzzi LA, Fisher YL, Guyer DR, et al. Central serous chorioretinopathy in younger and older adults. Ophthalmology 1996 Dec;103(12):2070-9; discussion 2079-80.

https://doi.org/10.1016/S0161-6420(96)30386-2

19. How AC, Koh AH. Angiographic characteristics of acute central serous chorioretinopathy in an Asian population. Ann Acad Med Singapore 2006 Feb;35(2):77-9.

20. Greisenegger S, Endler G, Hsieh K, Tentschert S, Mannhalter $\mathrm{C}$, LalouschekW. Is elevated mean platelet volume associated with a worse outcome in patients with acute ischemic cerebrovascular events? Stroke 2004 Jul;35(7):1688-91. https://doi.org/10.1161/01.STR.0000130512.81212.a2

21. Bath PM, Butterworth RJ. Platelet size: measurement, physiology and vascular disease. Blood Coagul Fibrinolysis 1996 Mar;7(2):157-61. https://doi.org/10.1097/00001721-199603000-00011

22. Cil H, Yavuz C, Islamoglu Y, Tekbas EÖ, Demirtas S, Atilgan ZA, et al. Platelet count and mean platelet volume in patients with in-hospital deep venous thrombosis. Clin Appl Thromb Hemost 2012 Nov;18(6):650-3.

https://doi.org/10.1177/1076029611435838

23. Hekimsoy Z, Payzin B, Ornek T, Kandoğan G. Mean platelet volume in type 2 diabetic patients. J Diabetes Complications 2004 May-Jun;18(3):173-6.

https://doi.org/10.1016/S1056-8727(02)00282-9

24. Şahin M, ŞahinA, Yüksel H, Türkcü FM, Yıldırım A. Mean platelet volume in patients with retinal artery occlusion. Arq Bras Oftalmol 2016 Feb;79(1):12-4.

https://doi.org/10.5935/0004-2749.20160005

25. Bain BJ, Imelda B. Basic haematological techniques. Dacie and Lewis Practical Haematology 9th ed Edinburgh, UK: Churchill Livingstone; 2001. pp. 19-46.

26. Akpinar I, Sayin MR, Gursoy YC, Karabag T, Kucuk E, Buyukuysal MC, et al. A platelet marker associated with saphenous vein graft disease. Herz 2014 Feb;39(1):142-8. https://doi.org/10.1007/s00059-013-3798-y

27. Ustundag Y, Huysal K, Gecgel SK, Unal D. Relationship between $\mathrm{C}$-reactive protein, systemic immune inflammation index, and routine hemogram-related inflammatory markers in low-grade inflammation. Int J Med Biochem 2018;1(1):24-8. https://doi.org/10.14744/ijmb.2017.08108

28. Okushiba U, Takeda M. Study of choroidal vascular lesions in central serous chorioretinopathy using indocyanine green angiography. Nippon Ganka Gakkai Zasshi 1997 Jan;101(1):74-82.

29. Chang MA, Bressler SB. Photodynamic therapy for chronic pigment epithelial detachment in central serous chorioretinopathy. Can J Ophthalmol 2009 Apr;44(2):221-2. https://doi.org/10.3129/i09-043

30. Yannuzzi LA. Central serous chorioretinopathy: a personal perspective. Am J Ophthalmol 2010;149:361-363. https://doi.org/10.1016/j.ajo.2009.11.017

31. Okushiba U, Takeda M. Study of choroidal vascular lesions in central serous chorioretinopathy using indocyanine green angiography. Nihon Ganka Gakkai Zasshi 1997;101:74-82.

32. Spaide RF, Hall L, Haas A, Campeas L, Yannuzzi LA, Fisher YL, et al. Indocyanine green videoangiography of older patients with central serous chorioretinopathy. Retina 1996;16:203-213. https://doi.org/10.1097/00006982-199616030-00004

33. Demirel S, Değirmenci MFK, Batığlu F, Özmert E. Evaluation of the choroidal features in pachychoroid spectrum diseases by optical coherence tomography and optical coherence tomography angiography. Eur J Ophthalmol 2021 Jan;31(1):184-193.

34. Filho MAB, de Carlo TE, Ferrara D, Adhi M , Baumal CR , Witkin AJ, et al. Association of choroidal neovascularization and central serous chorioretinopathy with optical coherence tomography angiography. JAMA Ophthalmol 2015; 133(8): 899-906.

https://doi.org/10.1001/jamaophthalmol.2015.1320

35. IijimaH, lida T, Murayama K, Imai M, Gohdo T.Plasminogen activator inhibitor 1 in central serous chorioretinopathy. Am J Ophthalmol 1999 Apr;127(4):477-8. https://doi.org/10.1016/S0002-9394(98)00378-X

36. Varol E, Icli A, Kocyigit S, Erdogan D, Ozaydin M, Dogan A. Effect of smoking cessation on mean platelet volume. Clin Appl Thromb Hemost 2013 Jun;19(3):315-9. https://doi.org/10.1177/1076029612436675

37. Türkcü FM, Yüksel H, Sahin A, Cinar Y, Cingü K, Arı S, et al. Effects of smoking on visual acuity of central serous chorioretinopathy patients. Cutan Ocul Toxicol 2014 Jun;33(2):115-9. https://doi.org/10.3109/15569527.2013.810633

38. DursunA, Toker MI, Ozec AV, Bozali E, Kirboga K, Dursun $\mathrm{FG}$, et al. Relationship between mean platelet volume and central serous chorioretinopathy. Int Ophthalmol 2017 Feb;37(1):119-124. https://doi.org/10.1007/s10792-016-0237-0 